\title{
DEATH AND DYING IN THE FORMATION PROCESS OF NURSES FROM THE PERSPECTIVE OF NURSING PROFESSORS
}

\author{
Danieli Bandeira1, Silvana Bastos Cogo², Leila Mariza Hildebrandt ${ }^{3}$, Marcio Rossato Badke ${ }^{4}$
}

${ }^{1}$ RN. Resident of the Integrated Multidisciplinary Residency Program in the Center for Health Sciences Public Health System
of the Federal University of Santa Maria (UFSM). Rio Grande do Sul, Brazil. E-mail: danielibandeira22@gmail.com
${ }^{2}$ Doctoral Student in Nursing of the Graduate Program in Nursing of the Federal University of Rio Grande (FURG). Assistant
Professor of the Department of Health Sciences of the Northern Rio Grande do Sul Centre for Higher Education (CESNORS)
of UFSM. Rio Grande do Sul, Brazil. E-mail: silvanabastoscogo@yahoo.com.br
${ }^{3}$ MSC in Psychiatric Nursing. Assistant Professor of CESNORS/UFSM. Rio Grande do Sul, Brazil. E-mail: leilahildebrandt@
yahoo.com.br
${ }^{4}$ MSC in Nursing. Assistant Professor of CESNORS/UFSM. Rio Grande do Sul, Brazil. E-mail: marciobadke@yahoo.com.br

ABSTRACT: This qualitative and descriptive study aimed to identify how nursing course professors approach death and dying in the university and what the implications are on the formation process. Ten professors of the undergraduate nursing course were intentionally selected and underwent semi-structured interviews, which were recorded. The thematic analysis of the data revealed that the presence of the fact caused insecurity in the interviewees and portrayed the lack of preparation in the undergraduate course, which could indicate a certain difficulty working with this theme. Furthermore, the interviewees highlighted the importance of working with death and dying. It is essential to understand the university to be a transforming agent of reflective subjects and a promoter of conditions for the student to experience the aspects involved in the care when faced with death.

KEYWORDS: Nursing. Death. Faculty, nursing. Nursing care.

\section{A MORTE E O MORRER NO PROCESSO DE FORMAÇÃO DE ENFERMEIROS, SOB A ÓTICA DE DOCENTES DE ENFERMAGEM}

RESUMO: Nesta pesquisa, delineada como qualitativa e descritiva, objetivou-se conhecer como os docentes de um curso de enfermagem abordam a morte e o morrer na academia e quais as implicações no processo de formação. Dez professores de um curso de graduação em enfermagem, intencionalmente selecionados, foram submetidos à entrevista semiestruturada, gravada. A análise temática dos dados permitiu constatar que a presença do fato provoca insegurança nos entrevistados e retrata a deficiência de preparo na graduação, o que pode indicar certa dificuldade ao se trabalhar com a temática. Apesar disso, os entrevistados evidenciaram a importância do trabalho acerca do processo de morte e morrer. É imprescindível o entendimento da academia, como agente transformadora de sujeitos reflexivos e promotora de condições para que o acadêmico vivencie as experiências envolvidas na assistência, diante da terminalidade. PALAVRAS CHAVE: Enfermagem. Morte. Docentes de enfermagem. Cuidados de enfermagem.

\section{MUERTE Y MORIR EN EL PROCESO DE FORMACIÓN DE ENFERMEROS DESDE LA PERSPECTIVA DE DOCENTES DE ENFERMERÍA}

RESUMEN: Estudio cualitativo e descriptivo que formuló como objetivo comprender como los docentes de enfermería abordan a la muerte y el morir en la academia y cuáles son las implicaciones en el proceso de formación. Diez profesores de graduación en enfermería fueron seleccionamos intencionalmente y respondieron las entrevistas semi-estructuradas, grabadas. El análisis temático de los datos reveló que la presencia con la muerte provoca inseguridad y retrata la deficiencia en la formación, lo que puede indicar una cierta dificultad en trabajar con el tema. Sin embargo, el análisis permitió constatar la importancia del trabajo en el proceso de muerte y morir. Es importante, que comprendamos la academia como un agente transformador y promotor de sujetos analíticos y de condiciones para que el estudiante vivencie experiencias asistenciales frente a la etapa terminal.

PALABRAS CLAVE: Enfermería. Muerte. Docentes de enfermería. Cuidados de enfermería. 


\section{INITIAL CONSIDERATIONS}

Death is an event present in the quotidian of people and arouses varied feelings and reactions. Although people possess awareness that their existence takes place within a cycle, which extends from birth to death, ${ }^{1}$ dying is often not seen as a natural process and is surrounded by mysteries and fears. It is known that the issues inherent in this process have been discussed, analyzed and experienced in various ways throughout history and by the different areas of knowledge. However, the healthcare area is the one that has most contact with this fact and therefore requires special attention. The same way that society deals with death in an attempt to exclude it from the quotidian, healthcare professionals also seem to use this subterfuge. It is often observed that they recognize their limits when working with patients with no the therapeutic possibilities of a cure and therefore the nursing care of those who die often becomes a burden, in a scenario of suffering, anguish and fear. Nurses, at the mercy of inner conflicts, feel failure in performing the work, which often contributes to their denial of the death and dying process. ${ }^{1-2}$

Faced with a situation of imminent death, many times, the members of the nursing team feel helpless, frustrated, guilty and angry, not knowing exactly how to position themselves when confronting the suffering and pain that, in the majority of cases, cannot be alleviated. Furthermore, they also have to experience the loss of patients, with whom, due to their coexistence, they may have established strong bonds. ${ }^{2}$ These difficulties are reflected in the care, as there are many nursing professionals who avoid caring for terminally ill patients or manifest apprehensive attitudes. This usually happens because they are not prepared to work with this fact in the same way they are with the maintenance of life. This lack of preparation and reflection on death leaves the professionals perplexed when making decisions in situations where they must care for the person at the stage of imminent death. ${ }^{2}$

From these difficulties in dealing with death and dying in the care for patients without the therapeutic possibility of a cure, it is necessary to reflect on the formation process of nurses, so that there are professionals qualified to deal with terminality. It is known that the nursing courses still provide limited space for work with the nurse/patient relationship and contact with the emotions and feelings arising from the interaction with patients and their families. ${ }^{2}$
The formation process in the healthcare area usually includes moments that contemplate theory and practice. In the theory, there is little talk about the subject and, in the practice, the student is inserted into the hospital routine and into the daily interaction with the particularities of the profession and facing death. ${ }^{1}$ Most of the time, this theme is barely discussed in the graduation course, which leads to a work directed only toward the practical and, almost always, disqualified. However, there are manifestations in various courses regarding the inclusion of discussions concerning terminality and thanatology into their curricula; the specialty of palliative medicine and the creation of elective disciplines focusing on this theme in undergraduate health area courses are indicative of this.

From this premise, there is a need for the inclusion of the theme of death and care for patients beyond the therapeutic possibility of a cure in the disciplines of the healthcare courses, especially in nursing. There are many adversities that nursing students experience when faced with such a situation and these contribute so that there is not only a gap in their training, but also a denial of the fact as an integral part of life and, as a consequence, the professionals are unprepared to provide integral care to people experiencing finitude and to their family members. The defensive system based on the denial of feelings and emotions feeds the paradox that on one hand healthcare professionals are the ones that deal more with the topic of death, while on the other they are also the most reluctant to recognize it as an inherent fact of the human existence. ${ }^{3}$ All this leads to a fragmentation of the work, because nurses are faced with their fears and anxieties and feel that their actions to provide care are limited.

Thus, it is imperative to know how the process of death and dying is approached in the undergraduate nursing course and, therefore, to contribute to discussions about the necessity of the formal preparation of the nurse in this process, as well as the qualification of the professors, as these are the developers of the theme in the disciplines in which they operate. Therefore, this study had as its research question: "how is the topic of death and dying approached by professors of a nursing course and what are the implications of this approach in the academic formation process?"

The aim of this study was to analyze how the professors of a nursing course approach death and dying in the university and what the implications are in the academic formation process. 


\section{METHODOLOGICAL PATHWAY}

This was a qualitative, descriptive study, performed in an undergraduate nursing course of a public university, located in the northern region of Rio Grande do Sul (RS), with the head office in the Central Region. The University, founded in 1970, has ten academic units throughout RS, and four elementary, technical and technological education establishments.

The subjects were ten professors, intentionally chosen, as they effectively participated in the formation process of the nurses, considering that they fulfill the role of promoters of discussions about the education for care in the dying process in the quotidian of the nursing course. The data collection occurred between May and June 2011, through semi-structured interviews, ${ }^{4}$ supported by questions inspired by the characterization of the subjects and the guiding themes of the investigation, that is, perceptions and experiences with the process of death and dying; approach of the theme during the formation; difficulties and ease in talking about death; and influences in the professional life.

The data were subjected to thematic analysis, ${ }^{4}$ which consisted of three phases: pre-analysis, exploration of the material, and processing and interpretation of the results. Thus, the data analysis was performed primarily by ordering the data, at which point the recordings were transcribed, with subsequent rereading of the material and organizing of the reports. Subsequently, the data were classified, based on issues relevant to their categorization. In the third step, the final analysis, the data and the theoretical references of the study were grouped according to the proposed

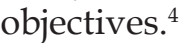

This study was approved by the Research Ethics Committee of the Federal University of Santa Maria (UFSM) (protocol n. 0056024300011) and followed the ethical guidelines established by Resolution no. 196/96 of the National Health Council, ${ }^{5}$ which include, among others, the Terms of Free Prior Informed Consent and the archiving of the interview transcripts for a period of five years.

\section{RESULTS AND DISCUSSION}

Seeking to answer the question of this study, the analysis of the data allowed the construction of three thematic units. Theme I: experiences of the professors, when they were students, regarding the process of death and dying; Theme II: approach of the death and dying theme, by the professors of the undergraduate nursing course; and Theme III: relevance of the approach of the death and dying process.

Of the ten teachers interviewed, eight were nurses, one a psychologist, and one a biologist. Regarding the length of time since graduating, four had less than 10 years, one 10 years, three over 20 years, and two over 30 years. With regard to the length of time that they had been working as professors, five had less than 10 years, one 10 years, three more than 20 years, and one more than 30 years.

\section{Professors' experiences, when they were students, regarding the death and dying process}

To understand how the nursing professors approach of the death and dying process, it is essential to know the way in which this issue was covered with them when they were students. The majority of the interviewees' statements allow the identification that the approach of the theme was: [...] in a weak and fragmented way [...] in one class [...] within a discipline, without further discussion (E1), with no specific discipline in the curriculum for this discussion to take place, generally, this topic was approached [...] in the discipline of law and professional ethics, in a very superficial way [...]. It was not a discipline or content that was deeply discussed (E4).

The best way to deal with the emotions that the subject of death raises is by not repressing or denying them but by allowing their development, ${ }^{1}$ and for this it is necessary for the healthcare professionals to receive another type of preparation in their formation. The absence of an approach toward this theme in the undergraduate nursing course has contributed so there is a gap in the formation, as well as a denial of this fact as an integral part of life, and as a result nurses are unable to enter into discussions about death and dying or to provide more comprehensive care to people experiencing finitude or to their family members. ${ }^{6-7}$

A major cause of the lack of preparation of the professors to work with the fact, in addition to the spiritual, cultural and personal aspects, is [...] the technicist teaching [...] more based on techniques [...] (E10), which valorizes a technical-scientific, impersonal, and mechanical formation, with emphasis on the disciplines that instrumentalize the care for the preservation of health and the cure 
of diseases, however, with little support related to taking care of the person who experiences the death process, ${ }^{8-9}$ as future nursing professionals.

From this, the following question arose: has the technicist focus offered in the nursing courses negatively impacted the care provided to patients who experience the process of death and dying and to their family? It is emphasized that the technical training of future healthcare professionals can not be dismissed. However, it is known that these professionals are often exposed to situations that involve facing the death of people under their care. However constantly they face this in their work quotidian, the difficulty in regarding it as an integral part of life is remarkable, often considering it to be a result of a weakness in the therapy and effort for the cure. In this sense, death creates disappointment in the professionals related to the ideals of omnipotence and efficiency inculcated from the academic formation, generating existential anxieties arising from the projection of the weakness in others and from the identification with the patient. ${ }^{3}$

From the graduation, nurses have difficulties in approaching patients who have no therapeutic possibility of a cure, since many obstacles occur when faced with problems arising from the daily existence; the first contact of the students with death is usually seen as [...] traumatic and [...] very hard (E10), and may arouse fantasies related to care actions that could have contributed to the death of the patient (E10). The feeling aroused in these situations translate into impotence, frustration, guilt, and irritation, among others, with such feelings being aroused both in the person who dies, as well as in those who witness this event. $2,7,10-11$

Some professors expressed calmness in coping with death/dying: the first experience with death, during the graduation, was very calm and minimized everything [...] the doubt, curiosity, even the fear, because it is difficult to face (E2). Thus, the ease of some professors in coping with this fact possibly stems from the experiences from their own graduation, from personal and spiritual issues, and from other past experiences.

Even though calmness when confronted with the issue was evidenced, the majority of the respondents reported varied feelings of frustration, anxiety, and guilt. Therefore, it is fundamental to discuss and reflect on the dilemmas of the concept of death that each person has and, through these, to enable the development of mechanisms to prepare these future professionals to cope with this situation. Furthermore, it is essential to offer emotional support during the graduation, emphasizing the implementation of thanatological education, in order to develop the ability to face this.

In this context, the following question became relevant: how will the professors who have experienced diverse situations of distress and suffering in relation to the theme approach this issue with their students? It is necessary to prepare healthcare professionals to care for patients beyond the therapeutic possibility of a cure in their graduation, as this makes up part of the skills that these professionals must possess in order to view the patient as a human being who needs to be helped in this stage of life. ${ }^{12}$

The statements also evidenced the [...] difficulty in relation to the family's situation [...] (E2). The dialogue with the family members of the patient without a therapeutic possibility of a cure, as well as the welcome, comfort, support, and even the preparation for communicating the death of their loved one to the family members, become difficult processes, where many professionals do not know how to cope, feeling helpless, fearful and insecure. ${ }^{13}$

It can be perceived that the way each person sees the phenomenon is different, as for some it is seen as a natural process, while for others it is an experience that is difficult to overcome. Despite all these problems, what was evidenced was the lack of preparation in the graduation course regarding the theme, with the prioritization of nursing techniques and care for the physical body of the patient, leaving aside patients and family members who experience difficulties and uncertainties arising from the death and dying process.

\section{Approach of the death and dying theme, by the professors of the undergraduate nursing course}

From the data obtained in this study it was found that the graduation course offered insufficient preparation for the students to undertake the care faced with the death/dying process. Studies on the theme claim that the lack of preparation in dealing with this phenomenon is often attributed to the academic formation and also emphasize that the graduation still does not prepare the professionals to reflect on finitude and experiencing this process ${ }^{10}$ which can also be evidenced in the statements of professors regarding the approach of death/dying [...] in the professional ethics discipline, 
[...] in a superficial way [...] (E4), and more practical than theoretical [...] (E5).

The results of studies conducted among professionals are also unanimous with regard to deficiencies faced during the academic formation. One study applied the "Attitude to death" questionnaire and found that $81.53 \%$ of the nurses presented a negative relationship towards death, associated with an undergraduate preparation to deal with the theme evaluated between poor and regular. ${ }^{14}$

Failure to approach the subject in the nursing disciplines was constantly evidenced by the professors: [...] I do not work with this in my quotidian. It seems to me that, just like my professors, I reproduce the same behavior. If the students ask, if the students provoke a discussion, I don't stop talking with them. However, I do not automatically put this in my list of disciplines, in my approaches during my classes, so I'll just discuss the issue if there is a question from the students (E6).

The statements reveal the lack of preparation of the nursing students to experience the death/ dying process of people who receive their care, most often occurring only in the practical field, without the theoretical support to face this. This fact can be attributed to the denial of feelings by the professor and the prevalence of technical actions at the detriment of humanized care, not only in relation to the patients and their family members, but also the students involved.

It is considered that not approaching the theme is due to the difficulties faced by professors in working with it, difficulties that often originate from the lack of professional preparation to work with death/dying: [...] I feel a lack of a more theoretical basis, with authors who better sustain what I am saying [...] I do not study a lot, so I do not have a theoretical foundation that best supports the discussion [...] (E6).

A study carried out with nursing professors highlighted that the professors reported the need to work with death, however did not know how to do it and, at the same time, reported their anguish over the issue, leading to anxiety, loneliness and skepticism in relation to their capacity to act in this situation. ${ }^{15}$ This lack of preparation on their part is most often reflected in the nursing students, who face difficulties when working with this process: [...] the students are unprepared for it and [...] the professionals at the internship and activity sites have difficulties addressing this theme, dealing with it, or breaking the news of death, perhaps due to the involvement they have with these patients (E5).
It is known that studying death is something that can help working with its constant presence, therefore it is necessary that the professional is familiar with death from the graduation, with a view to personal and professional preparation in such a way as to reduce the stress and anxiety when faced with situations of suffering, providing the professional with the development and clarification of their concerns faced with the unknown. ${ }^{6}$

Thus, the approach to the subject only in the practical field is not enough to prepare nursing students to cope with care in the death/dying process. It is known that when providing the student with clarification regarding what death really is the professor enriches the knowledge of the student concerning this process. It is also essential for each professor to provoke moments of reflection and supervision after the first experiences of the students with the fact, so that they feel more secure and prepared to encounter such an occurrence in the future, as they demonstrate the necessity for spaces of reflection and emotional support in the professional quotidian. ${ }^{3}$ Nevertheless, what the statements show is the lack of discussion of the subject by the professors, that is, in the same way that they did not have a qualified approach to the subject in their formation, as professors, they reproduce this absence.

While the professors recognize the deficient approach to the death/dying theme in the political-pedagogical projects of the nursing courses, as well as the lack of involvement of the nursing students in these situations, the majority of them report that they do not address the theme, with the excessive programmatic content related to the working hours of the discipline as the justification: [...] I think the our problem with the course is the lack of working hours. If you think about the ethics discipline, there is a variety of content in one discipline of 30 classroom hours, so I think that is why, at this moment it is because of this [...] (E4).

Complementary to this concept is forgetting the theme: [...] I just remembered death when I went into the field where we are faced with the practical and remember this detail (E1), or even considering it as the responsibility of other disciplines of the course: $d u e$ to the specificity of the discipline, because I understand that this question of death/dying is closer to the specific nursing disciplines. As I work more with the question of administration, normally this runs parallel, not that it does not have importance, but it runs parallel (E6).

From this, the following questions arise: is the approach of this topic in the ethics and legis- 
lation discipline enough to prepare students for coping with death/dying? Should the disciplines be distributed in such a manner that they do not have the multidisciplinarity necessary for a more consistent and cohesive formation in the subject? In order for students to have support for the exercise of their activities, enabling them to gradually become accustomed to situations of death, it is essential to establish a commitment to work with the theme in an multidisciplinary way. ${ }^{16}$ Accordingly, the importance is highlighted of constantly covering with the death and dying process, not only in one specific discipline, but throughout the graduation, so that it is possible to establish a broader and deeper discussion on the theme.

Another point to be highlighted is the lack of working hours reported by the respondents, with the need to redesign the pedagogical proposal of the undergraduate healthcare courses, in order to contemplate a view beyond that of the technicalscientific formation. ${ }^{12}$ In this sense, a possible change in the political-pedagogical project could contribute to enhance the humanistic formation of healthcare professional and prepare them to offer dignified care that meets the needs of people who experience the death and dying process and those of their family members.

\section{Relevance of the approach of the death and dying process}

The nurse needs to comprehend death and not just explain it. To capture this knowledge, it is essential that the education goes beyond the biological considerations and allows students to reflect on the theme, with greater appropriation of the content of sociology, anthropology, philosophy, and psychology, as well as self-knowledge and permanent work in the emotional sphere. ${ }^{16}$ Nursing is one of the main professions of the healthcare area that deals with death, since the nurse provides the simplest to the most complex care for the patients, also including the patients beyond the therapeutic possibility of a cure.

In this sense, it is essential that nurses learn to work with this process through education about death. This is understood as education about the death that occurs in the quotidian, involving communication, relationships, losses, and limited situations, in which changes can occur at any stage of the development and is grounded in questions, in the search for self-knowledge and the meaning of life. ${ }^{17}$ The importance of the appropriation of this theme is evidenced by the professors, who consider it [...] essential and independent of the area of practice, because we deal with death in all the areas, some more, others less [...], so, regardless of the area in which we practice, I think we need this reference (E4).

To work with the process of death and dying in the university means offering support for students to understand this phenomenon as a process in which the subject of the action is the patient and therefore their family. ${ }^{10}$ From the discussion of the importance of the approach of the theme in the nursing curricula, the possibility of the inclusion of the subject as a Complementary Undergraduate Discipline (CUD) emerged from the statements of the interviewees, because it is [...] content that should transverse the course and must be covered in all the course disciplines that have a more intimate relationship with the death event [...] (E10). The importance of creating a CUD is emphasized, as the majority of healthcare institutions have an increasingly older population, with chronic diseases, with families asking for help to work with dealing with death. So I guess that in nursing we have to prepare ourselves to work with this situation [...] (E4).

In an integrative review of death and its implications in academic teaching, it was found that professors, students and healthcare professionals are unprepared to deal with situations where patients are experiencing the death and dying process, evidenced by feelings of fear, suffering and estrangement. However, the same reference indicates that the undergraduate courses in the healthcare area attach little or no importance to discussions involving human terminality, which is worrying as these professionals are faced with death in the different healthcare services. ${ }^{18}$

Based on the foregoing, in the higher education institution in which the study occurred, a CUD of 30 hours was created, offered to the students in the second semester of nursing, entitled "Death and dying: contributions to nursing care", the intention of which was to appropriate the theoretical framework and to reflect on this theme directed towards care for people who are dying and their family members, in order to minimize the suffering caused by the theme. The importance of the initiative for the creation of the CUD is emphasized, since there are few nursing courses that include the theme in their curricula. The creation of a discipline will not solve the problem, thus making it necessary to establish a commitment to work with the subject in an multidisciplinary way, involving all the professors. ${ }^{16}$ 
However, the creation of thanatology groups, which provide the students with the theoretical support to implement their activities, is suggested.$^{16}$ It is considered that the creation of a CUD would be of great value for the inclusion of the theme into the nursing curricula, however, only one discipline committed to the theme, is not enough for an adequate preparation for coping with death/dying. It is therefore necessary that this matter be placed on the agenda throughout the academic formation process, so that an education about death can be implemented, which corresponds to the requirements of the future nurses.

It is emphasized that formal education about death could be transformed into a space to construct new meanings and new ways of intervention regarding the reality, and may enable the overcoming of the alienation and more complete human development. For this, in addition to the inclusion of new content, it is necessary to combine theoretical-technical knowledge with the development of skills and competencies that focus on the subject, the subjectivity and the care for the self and others who are experiencing the process of finitude. ${ }^{19}$ Furthermore, the importance of education to sensitize healthcare professionals in relation to the practice of watching the death and dying process is emphasized, encouraging the construction of relationship networks between the educational institutions and the services, so that humanization can be adopted as the concept and element of the nursing care systematization methodology. ${ }^{11}$

\section{FINAL CONSIDERATIONS}

This study did not aim to exhaustively investigate this theme, especially considering the limitations when studying a topic that involves the subjectivity of the individuals. However, it can be said that these results show the reality experienced in a public university in the state of Rio Grande do Sul.

When healthcare professional perceive death as a natural process and the destiny for everyone, they cease to regard it as a weakness of their profession. Accordingly, it is essential to develop studies that enable them to develop selfknowledge and interventions that help assist the patient and family faced with the death/dying process, minimizing their psychological suffering.

The study highlighted a certain fragmentation in the treatment of the theme in the under- graduate nursing course, not having a space for the discussion of the experiences and implications that the event has for the students. The role of the university is emphasized in relation to enabling the student to be able to establish interpersonal relationships of help for the patients who experience this process and their family members. Therefore, it is necessary to create spaces for discussion and reflection, which may lead the nursing student to achieve a clearer comprehension with respect to death. This highlights the importance of the inclusion of the theme in the curricula of the nursing professional graduation courses, as well as its inclusion in the hospitals, through ongoing education, seeking strategies that promote changes in the attitudes of professionals toward the patient beyond the therapeutic possibility of a cure.

In order for nursing students to cope with the issues of the death/dying process, it is essential that, during their graduation, they are prepared to face this. Therefore, it is necessary to approach the issues of thanatology during the university course. Furthermore, the professors must be able to work with this theme. Based on this assumption, it is essential that this theme be placed on the agenda in the university and that the professors are sensitized for their improvement, aiming towards a better approach regarding education concerning death.

It is understood that all the responsibility for the professional unpreparedness to work with situations of imminent death should not be placed on the graduation process, as it is understood to be essential to rethink the family, spiritual and educational experiences, starting from the elementary and high school education. However, it is essential to understand the university as a transforming agent of reflective subjects and a promoter of conditions for the student to experience the aspects involved in the care faced with the death/dying process.

The issues inherent in the death/dying process permeate the nurse-patient relationship, as well as the relationships with the family members. Accordingly, there is an understandable urgency for the discussion and debate on the issue in nursing education, focusing on emotional preparation and interpersonal relationships of the students as they face this process. It is therefore necessary to create spaces in which to share experiences that contribute to combining the best approach with the best way to implement the theme in the undergraduate nursing courses. 
The creation of a CUD encompassing issues of the death/dying process is an important advance for the inclusion of the discussion of the theme in the curriculum of the nursing courses. However, it is understood that the creation of a CUD will not resolve the academic deficiencies in relation to the subject. It is necessary to go further, as this is content that evidences the need for a transversal approach in the course and in all the disciplines that have an intimate relationship with the death event.

\section{REFERENCES}

1. Santos FS, organizador. A arte de morrer: visões plurais. São Paulo (SP): Comenius; 2009.

2. Kovács MJ. Educação para a morte: desafio na formação de profissionais de saúde e educação. São Paulo (SP): Casa do Psicólogo; 2003.

3. Santos MA, Hormanez M. Atitude frente à morte em profissionais e estudantes de enfermagem: revisão da produção científica na última década. Ciência Saúde Coletiva. 2013; 18(9):2757-68.

4. Minayo MCS. O desafio do conhecimento: pesquisa qualitativa em saúde. $12^{\mathrm{a}}$ ed. São Paulo (SP): Hucitec; 2010.

5. Ministério da Saúde (BR). Conselho Nacional de Saúde, Comissão Nacional de Ética em Pesquisa. Resolução n. 196 de 10 de outubro de 1996: diretrizes e normas regulamentadoras de pesquisa envolvendo seres humanos. Brasília (DF): MS; 1996.

6. Sousa DMS, Soares EO, Costa KMS, Pacífico ALC, Parente ACM. A vivência da enfermeira no processo de morte e morrer dos pacientes oncológicos. Texto Contexto Enferm. 2009 Jan-Mar; 18(1):41-7.

7. Sadala MLA, Silva FM. Cuidando de pacientes em fase terminal: a perspectiva de alunos de enfermagem. Rev Esc Enferm USP. 2009; 43(2):287-94.

8. Bifulco VA, Iochida LC. A formação na graduação dos profissionais de saúde e a educação para os cuidados de pacientes fora de recursos terapêuticos de cura. Rev Bras Educ Med. 2009; 33(1):92-100.

9. Pinho LMO, Barbosa MA. A relação docenteacadêmico no enfrentamento do morrer. Rev Esc Enferm USP. 2010; 44(1):107-12.

10. Lima MGR, Nietsche EA, Teixeira JA. Reflexos da formação acadêmica na percepção do morrer e da morte por enfermeiros. Rev Eletr Enf. 2012. Jan-Mar; 14(1):181-8.

11. Cantídio FS, Vieira MA, Sena RR. Significado da morte e de morrer para os alunos de enfermagem. Invest Educ Enferm. 2011; 29(3):407-18

12. Takahashi CB, Contrin LM, Beccaria LM, Goudinho MV, Pereira RAM. Morte: percepção e sentimentos de acadêmicos de enfermagem. Arq Ciênc Saúde. 2008. Jul-Set; 15(3):132-8.

13. Santos JL, Bueno SMV. Educação para a morte a docentes e discentes de enfermagem: revisão documental da literatura científica. Rev Esc Enferm USP. 2011; 45(1):272-6.

14. Cabrera MM, Gutiérrez MZ, Escobar JMM. Actitud del professional de enfermeria ante la muerte de pacientes. Cienc Enferm. 2009; 30(2):289-96.

15. Sulzbacher M, Reck AV, Stumm EMF, Hildebrandt LM. O enfermeiro em Unidade de Tratamento Intensivo vivenciando o enfrentando situações de morte e morrer. Sci Med. 2009; 19(1):11-6.

16. Oliveira WIA, Amorim RC. A morte e o morrer no processo de formação do enfermeiro. Rev Gaúcha Enferm. 2008. Jun; 29(2):191-8.

17. Kovács MJ. Desenvolvimento da tanatologia: estudos sobre a morte e o morrer. Paidéia. 2008; 18(41):457-68.

18. Lima MGR, Nietsche EA, Santos SC, Teixeira JA, Bottega JC, Nicola GDO, et al. Revisão integrativa: um retrato da morte e suas implicações no ensino acadêmico. Rev Gaúcha Enferm. 2012; 33(3):190-97.

19. Combinato DS, Queiroz MS. Um estudo sobre a morte: uma análise a partir do método explicativo de Vigotski. Ciência Saúde Coletiva. 2011; 16(9):3893900. 